\title{
Modelling the effect of denitrification on polar ozone depletion for Arctic winter 2004/2005
}

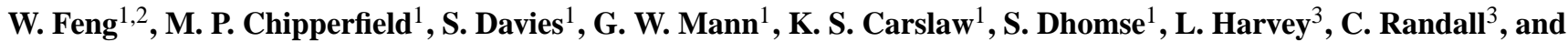 \\ M. L. Santee ${ }^{4}$ \\ ${ }^{1}$ NCAS, Institute for Climate and Atmospheric Science, School of Earth and Environment, University of Leeds, Leeds, UK \\ ${ }^{2}$ Mathematics and Physical Sciences, School of Chemistry, University of Leeds, Woodhouse Lane, Leeds, LS2 9JT, UK \\ ${ }^{3}$ Laboratory for Atmospheric and Space Physics, University of Colorado, Boulder, Colorado, USA \\ ${ }^{4}$ Jet Propulsion Laboratory, California Institute of Technology, Pasadena, California, USA
}

Received: 23 December 2010 - Published in Atmos. Chem. Phys. Discuss.: 2 February 2011

Revised: 20 June 2011 - Accepted: 4 July 2011 - Published: 12 July 2011

\begin{abstract}
A three-dimensional (3-D) chemical transport model (CTM), SLIMCAT, has been used to quantify the effect of denitrification on ozone loss for the Arctic winter 2004/2005. The simulated $\mathrm{HNO}_{3}$ is found to be highly sensitive to the polar stratospheric cloud (PSC) scheme used in the model. Here the standard SLIMCAT full chemistry model, which uses a thermodynamic equilibrium PSC scheme, overpredicts the ozone loss for Arctic winter 2004/2005 due to the overestimation of denitrification and stronger chlorine activation than observed. A model run with a coupled detailed microphysical denitrification scheme, DLAPSE (Denitrification by Lagrangian Particle Sedimentation), is less denitrified than the standard model run and better reproduces the observed $\mathrm{HNO}_{3}$ as measured by Airborne SUbmillimeter Radiometer (ASUR) and Aura Microwave Limb Sounder (MLS) instruments. Overall, denitrification is responsible for a $\sim 30 \%$ enhancement in $\mathrm{O}_{3}$ depletion compared with simulations without denitrification for Arctic winter 2004/2005, which is slightly larger than the inferred impact of denitrification on Arctic ozone loss for previous winters from different CTMs simulations. The overestimated denitrification from standard SLIMCAT simulation causes $\sim 5-10 \%$ more ozone loss at $\sim 17 \mathrm{~km}$ compared with the simulation using the DLAPSE PSC scheme for Arctic winter 2004/2005. The calculated partial column ozone loss from SLIMCAT using the DLAPSE scheme is about 130 DU by mid-March 2005, which compares well with the inferred column ozone loss from ozonesondes and satellite data (127 $\pm 21 \mathrm{DU})$.
\end{abstract}

Correspondence to: W. Feng

(w.feng@leeds.ac.uk)

\section{Introduction}

Significant progress has been made in understanding the processes controlling the observed polar stratospheric ozone depletion during the recent decades through measurements, laboratory work and modelling studies (e.g., Solomon, 1999; Chipperfield et al., 2005). Previous extensive studies have shown that successfully understanding polar stratospheric ozone depletion depends crucially on the processes of polar stratospheric clouds (PSCs) in activating chlorine and denitrifying the stratosphere (e.g., Tabazadeh et al., 2000; WMO, 2006). Although the main processes that lead to ozone depletion are generally well understood, there remain open questions such as the duration of chlorine activation and its dependence on the abundance of nitrogen oxides (Kühl et al., 2004).

Reactive nitrogen $\left(\mathrm{NO}_{\mathrm{y}}\right)$ species play an important role in the chemistry of stratospheric $\mathrm{O}_{3}$, both directly through rapid catalytic cycles involving $\mathrm{NO}_{\mathrm{x}}$ and indirectly through their interaction with e.g. halogen species. As stratospheric halogen levels decline, the role of $\mathrm{NO}_{\mathrm{y}}$ species may become more important. However, over the past few years there have been a number of updates to laboratory data related to $\mathrm{NO}_{\mathrm{y}}$ chemistry (e.g., Sander et al., 2006). In addition, studies using photochemical models have indicated problems in reproducing the observed abundance of $\mathrm{NO}_{\mathrm{y}}$ and its partitioning into its components (e.g., Sen et al., 1998; Dufour et al., 2005). Denitrification is defined as the permanent removal of $\mathrm{NO}_{\mathrm{y}}$ from a stratospheric air mass by the sedimentation of $\mathrm{HNO}_{3}$-containing particles (e.g., Fahey et al., 1990; WMO, 2010). Significant denitrification leads to an increase in the lifetime of ozone-depleting chlorine species $\left(\mathrm{ClO}_{\mathrm{x}}\right)$

Published by Copernicus Publications on behalf of the European Geosciences Union. 
and therefore leads to an increase in the duration and extent of springtime polar ozone loss (e.g., Waibel et al., 1999; Esler and Waugh, 2002; Davies et al., 2002).

The Arctic winter 2004/2005 was one of the coldest winters ever recorded in the stratosphere, and has been studied extensively (e.g., Manney et al., 2006; Rex et al., 2006; von Hobe et al., 2006; Feng et al., 2007a; Singleton et al., 2007; Rosevall et al., 2008). Feng et al. (2007a) found that an updated version of the SLIMCAT 3-D chemical transport model (CTM) (Chipperfield, 2006) overestimated the observed ozone loss in the cold Arctic winter of 2004/2005. Therefore, further investigations of the processes which lead to Arctic ozone depletion are required to better understand the discrepancies between models and observed ozone loss. Previously models had systematically underestimated Arctic ozone loss in cold winters (e.g., Becker et al., 1998; Rex et al., 2004; Feng et al., 2005a; Chipperfield et al., 2005 and Singleton et al., 2005). More details of the updated SLIMCAT version can be found in Feng et al. (2005a, 2007b), Chipperfield et al. (2005) and Chipperfield (2006).

In this paper, we investigate the impact of using different model PSC schemes, including effect of denitrification on the ozone loss for the Arctic winter 2004/2005. We use airborne and satellite remote sensing observations from the Airborne Submillimeter Radiometer (ASUR) and Aura Microwave Limb Sounder (MLS) instruments to test the denitrification simulated by the model for the different PSC schemes.

\section{ASUR and Aura MLS measurements}

The ASUR (Küllmann et al., 1999; Kleinböhl, 2004) is an airborne radiometer measuring the thermal emission of trace gases in the stratosphere. The profile retrieval is performed on equidistant altitude levels of $2 \mathrm{~km}$ spacing (Kleinböhl, 2004). The instrument was successfully operated on board the NASA DC-8 research aircraft in the Polar Aura Validation Experiment (PAVE) over the period of 24 January to 9 February 2005 remotely measuring the trace gases $\mathrm{HCl}$, $\mathrm{O}_{3}, \mathrm{ClO}, \mathrm{N}_{2} \mathrm{O}$ and $\mathrm{HNO}_{3}$ in the altitude range 14 to $40 \mathrm{~km}$ (Kleinböhl et al., 2005; Kuttippurath et al., 2004). The vertical resolution of these measurements is given by the width of the averaging kernels $(\sim 6-20 \mathrm{~km})$, decreasing with altitude from the lower to upper stratosphere (e.g., Kleinböhl, 2004; Kuttippurath et al., 2011). The total typical retrieval error is $\sim 20 \%$ for $\mathrm{HCl}, \sim 10 \%$ for $\mathrm{ClO}$, and less than $15 \%$ for $\mathrm{N}_{2} \mathrm{O}$ and $12 \%$ for $\mathrm{O}_{3}$ (e.g., von König, 2002; Bremer et al., 2002; Kleinböhl, 2004; Kuttipurath et al., 2007).

The Earth Observing System (EOS) MLS is an instrument on the NASA Aura satellite, launched on 15 July 2004. It observes a large suite of atmospheric parameters by measuring millimetre and submillimetre wavelength thermal emission from the Earth's limb viewing forward along the Aura spacecraft flight track. Vertical profiles of $\mathrm{O}_{3}, \mathrm{HNO}_{3}, \mathrm{ClO}, \mathrm{HCl}$,
$\mathrm{N}_{2} \mathrm{O}, \mathrm{H}_{2} \mathrm{O}, \mathrm{CO}$ and other chemical compounds are retrieved. The horizontal and vertical resolution of the MLS retrievals, given below for each species of relevance, are obtained from the MLS averaging kernels (for details see the Aura MLS v3 Data Quality Document, Livesey et al., 2011). Aura MLS has better spatial resolution and coverage than the predecessor UARS MLS instrument with measurement made globally on daily basis. A feature of the MLS and ASUR technique is that its measurements can be obtained in the presence of ice clouds and aerosol, that prevent measurements by shorterwavelength infrared, visible and ultraviolet techniques (for more information about MLS, see Schoeberl et al., 2006; Livesey et al., 2006; Waters et al., 2006; Santee et al., 2007; Santee et al., 2008). The MLS data used in this paper is version 3.3 (MLS v3.3) which has been released in 2011 (Livesey et al., 2011). The Aura MLS data for the 2004/2005 Arctic winter has been described in detail by Schoeberl et al. (2006) and Santee et al. (2008). The MLS v3.3 data has different recommended vertical range, i.e., $147-1.0 \mathrm{hPa}$ for $\mathrm{ClO}, 100-0.32 \mathrm{hPa}$ for $\mathrm{HCl}, 215-1.5 \mathrm{hPa}$ for $\mathrm{HNO}_{3}, 100$ $0.46 \mathrm{hPa}$ for $\mathrm{N}_{2} \mathrm{O}$ and $261-0.02 \mathrm{hPa}$ for $\mathrm{O}_{3}$. The vertical resolution for $\mathrm{ClO}$ is $3-4.5 \mathrm{~km}$ and the uncertainty is about $5-20 \%$. $\mathrm{HCl}$ has $3 \mathrm{~km}$ vertical resolution and the uncertainty is about $10 \%$ above $20 \mathrm{hPa}$ with a large variable uncertainty with latitude and season in the lower stratosphere, due to the variability in $\mathrm{HCl}$. The vertical resolution of the $\mathrm{HNO}_{3}$ data is $3-4 \mathrm{~km}$ through most of the useful range, degrading to about $5 \mathrm{~km}$ at $22 \mathrm{hPa}$. The uncertainty of $\mathrm{HNO}_{3}$ is $5-10 \%$ between $100-6.8 \mathrm{hPa} . \mathrm{O}_{3}$ data has about $2.5 \mathrm{~km}$ vertical resolution and 5-10\% uncertainty in the uppermost troposphere and stratosphere. The MLS v3.3 $\mathrm{N}_{2} \mathrm{O}$ has coarse vertical resolution (4-6 km) over most of the useful range of the retrievals and the uncertainty varies with height from 9$25 \%$. For detailed MLS v3.3 information see http://mls.jpl. nasa.gov/data/v3-3_data_quality_document.pdf.

The ASUR and MLS data are very useful for understanding stratospheric ozone depletion and for validating atmospheric chemical transport models. Here we concentrate on the chemical species $\mathrm{HNO}_{3}, \mathrm{HCl}, \mathrm{ClO}, \mathrm{O}_{3}$ and $\mathrm{N}_{2} \mathrm{O}$. The observations of $\mathrm{HNO}_{3}$ during the polar winter allow the quantification of denitrification. The ASUR $\mathrm{HNO}_{3}$ observations have been successfully used to quantify denitrification in the Arctic winters 2000 and 2005 (e.g., Kleinböhl et al., 2002, 2005). The chlorine compounds $\mathrm{HCl}$ and $\mathrm{ClO}$ permit a testing of chlorine activation and other related chemical processes (e.g., Santee et al., 2008). $\mathrm{N}_{2} \mathrm{O}$ will be used to determine changes due to atmospheric dynamics in the polar region (i.e., diabatic descent of air masses in the atmosphere) and validate the model transport. $\mathrm{O}_{3}$ data will be used to estimate the polar ozone depletion. 


\section{Model and experiments}

SLIMCAT is an off-line 3-D CTM described in detail by Chipperfield $(1999,2006)$ which now uses a hybrid $\sigma-\theta$ as vertical coordinate and includes the atmosphere from the surface up to $\sim 60 \mathrm{~km}$. The model has been widely used to study transport and chemistry in the upper troposphere and lower stratosphere (UTLS) (e.g., Feng et al., 2005a, b; Chipperfield, 2006; Feng, 2006; Feng et al., 2007a, b). Horizontal winds and temperatures are specified using meteorological analyses. Vertical advection is calculated from diabatic heating rates using a NCAR chemistry climate model (CCM) radiation scheme (Briegleb, 1992) which gives a better representation of vertical transport in the model (see Feng et al., 2005a). Chemical tracers in SLIMCAT are advected using the scheme of Prather (1986) which conserves secondorder moments and performs well in maintaining strong gradients. The model contains the principal stratospheric chemical species in the $\mathrm{O}_{\mathrm{x}}, \mathrm{HO}_{\mathrm{x}}, \mathrm{NO}_{\mathrm{y}}, \mathrm{Cl}_{\mathrm{y}}, \mathrm{Br}_{\mathrm{y}}$ families as well as source gases (i.e., $\mathrm{N}_{2} \mathrm{O}, \mathrm{CH}_{4}, \mathrm{CFCl}_{3}, \mathrm{CF}_{2} \mathrm{Cl}_{2}, \mathrm{CH}_{3} \mathrm{Br}$ ) and a treatment of $\mathrm{CH}_{4}$ oxidation. The photochemical data is based on the JPL recommendation (Sander et al., 2006) with the exception of the absorption cross sections of $\mathrm{Cl}_{2} \mathrm{O}_{2}$ which is taken from Burkholder et al. (1990) extrapolated to $450 \mathrm{~nm}$. The Burkholder et al. (1990) cross-section (updated by Papanastasiou et al., 2009) are larger than other laboratory measurements, and have been found to reproduce the observed Arctic ozone loss rate (see SPARC, 2009). The model contains a detailed gas-phase stratospheric chemistry scheme and also a treatment of heterogeneous reactions on liquid aerosols, nitric acid trihydrate (NAT) and ice (see Chipperfield, 1999).

The standard SLIMCAT model uses a simplified PSC scheme for the simulation of heterogeneous chemistry and denitrification. This scheme is based on the assumption of thermodynamic equilibrium between the particles formed (whether liquid aerosol, NAT or ice) and the gas phase (e.g., Davies et al., 2002; Davies, 2003; Feng et al., 2005a, 2007a, b; Chipperfield et al., 2005). The equilibrium model assumes NAT forms in two modes (radius 0.5 and $6.5 \mu \mathrm{m}$ ), which is the same as the scheme described by Davies et al. (2002) and tested for the cold Arctic winter of 1999/2000 (Feng et al., 2005a). In this scheme NAT particles are sedimented from the model with fall velocities of 1 and $1100 \mathrm{~m} /$ day appropriate for particles of radius 0.5 and $6.5 \mu \mathrm{m}$, respectively. Ice particles with an assumed radius of $10 \mu \mathrm{m}$ are sedimented at a rate of $1500 \mathrm{~m} /$ day.

However, a full microphysical PSC scheme is required for a detailed simulation of Arctic denitrification. Previous studies (e.g., Davies et al., 2002, 2006; Davies, 2003; Mann et al., 2002, 2003, 2005) used the separate microphysical Denitrification by Lagrangian Particle Sedimentation (DLAPSE) model to investigate denitrification effect in Arctic winters, but only Davies et al. (2006) combined this with the full SLIMCAT chemistry. These studies advected gas phase
Table 1. SLIMCAT model experiments.

\begin{tabular}{lll}
\hline Runs & Denitrification scheme & Reference \\
\hline EXP_A & Thermodynamical equilibrium & Feng et al. (2007a) \\
EXP_B & Microphysical DLAPSE & Davies et al. (2006) \\
EXP_C & No Denitrification & \\
\hline
\end{tabular}

$\mathrm{HNO}_{3}$ in SLIMCAT, interpolated to the Lagrangian particle positions, then ran the DLAPSE model to calculate the growth and sedimentation of several hundred thousand particles (more details can be found in Davies, 2003). In Davies et al. (2006), they were running two independent models (DLAPSE and SLIMCAT) and passing information between these two models. For this work, we have fully incorporated the Lagrangian particle denitrification model (DLAPSE) into the SLIMCAT model to extend the options of PSC scheme in the model. The coupled DLAPSE model uses the Lagrangian trajectory scheme contained in the SLIMCAT model (see Monge-Sanz et al., 2007). This is an improvement over the standard model because it calculates the growth and sedimentation of individual particles and is suitable for the simultaneous simulation of several hundred thousand particles (Carslaw et al., 2002). Despite the microphysical detail, the coupled DLAPSE model is computationally efficient as it only performs calculations when NAT particles are present and does not add any additional 3-D tracers in the model.

Three model experiments with different treatment of PSCs were run for the Arctic winter of 2004/2005. Table 1 lists the different denitrification schemes used in SLIMCAT. Experiment A (EXP_A) is the standard SLIMCAT full chemistry run as described in Feng et al. (2007a), Experiment B (EXP_B) is the full chemistry run using the microphysical DLAPSE scheme. Here we used a constant volume average NAT nucleation rate $\left(8.1 \times 10^{-10}\right.$ particles $\left.\mathrm{cm}^{-3} \mathrm{~s}^{-1}\right)$. NAT particles are initialised with a radius of $0.1 \mu \mathrm{m}$. Finally, Experiment C (EXP_C) had denitrification switched off (no sedimentation). All of these model experiments used 24 vertical levels extending from the surface to $\sim 60 \mathrm{~km}$ and a horizontal resolution of $2.8^{\circ} \times 2.8^{\circ}$. The model was forced by 6-hourly European Centre for Medium-Range Weather Forecasts (ECMWF) operational analyses.

\section{Results}

Kleinböhl et al. (2005) reported that the NASA DC-8 research aircraft sampled air from the Arctic polar vortex on 31 January and 5 February 2005. Schoeberl et al. (2006) also investigated the process of filament formation and estimated the vortex denitrification using the measurements from aircraft and Aura MLS satellite observed on 31 January 2005. Figure 1 shows profiles of $\mathrm{HNO}_{3}, \mathrm{HCl}, \mathrm{ClO}, \mathrm{O}_{3}$ and $\mathrm{N}_{2} \mathrm{O}$ 

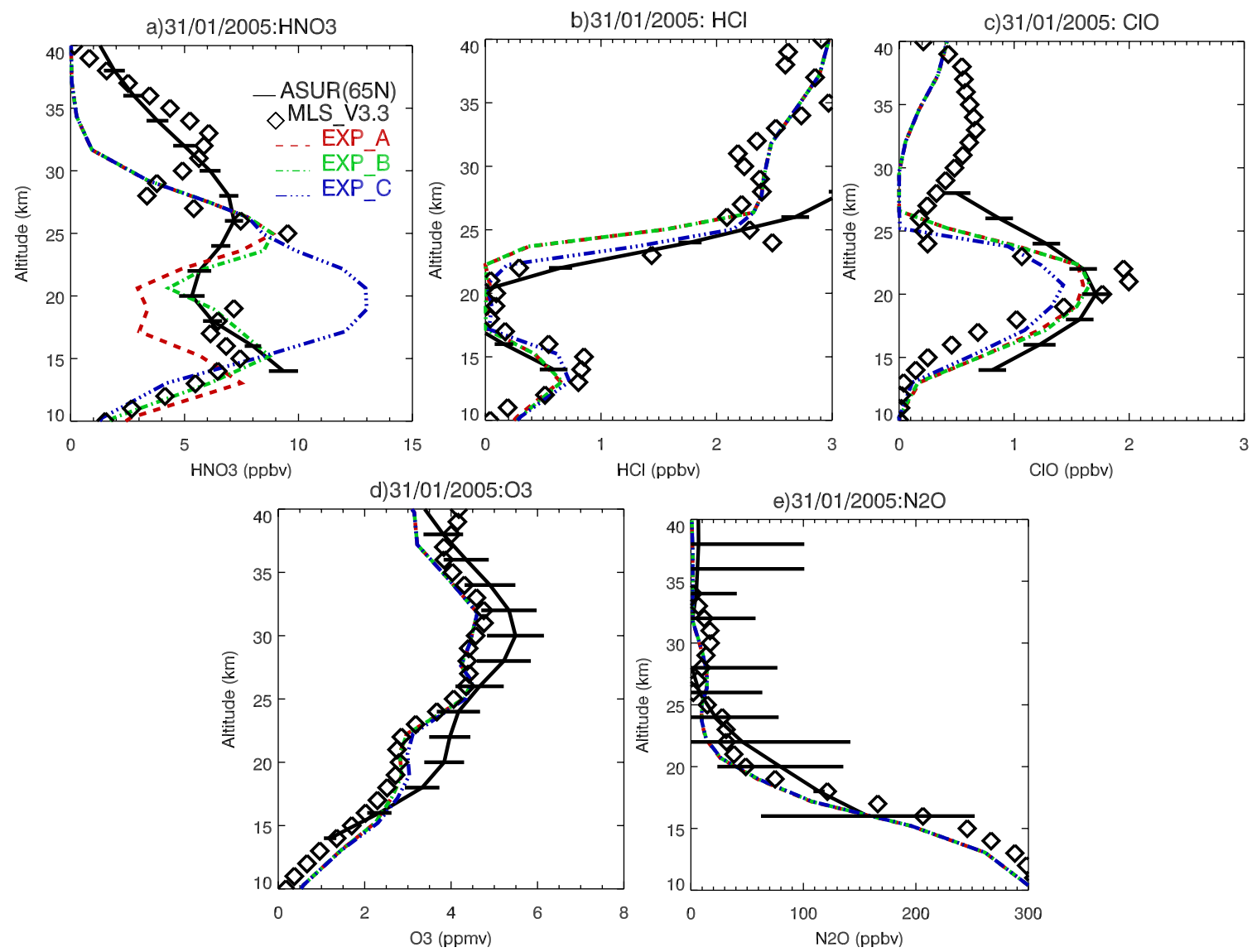

Fig. 1. Profiles of $\mathrm{HNO}_{3}, \mathrm{HCl}, \mathrm{ClO}, \mathrm{O}_{3}$ and $\mathrm{N}_{2} \mathrm{O}$ from ASUR and MLS observations and model simulations using the equilibrium (EXP_A), DLAPSE (EXP_B) PSC schemes and without denitrification (EXP_C) for 31 January 2005.

from ASUR, MLS and the three SLIMCAT simulations for 31 January 2005. Figure 2 is similar to Fig. 1 but for 5 February 2005. The observed $\mathrm{HNO}_{3}$ decreases with increasing altitude from $\sim 13$ to $\sim 22 \mathrm{~km}$, increases with altitude to $\sim 26 \mathrm{~km}$ and then decreases again in the middle and upper stratosphere. Obviously, there is a significant denitrification occurred in the lower stratosphere. $\mathrm{MLS} \mathrm{HNO}_{3}$ has a very similar profile below $20 \mathrm{~km}$ and above $25 \mathrm{~km}$ with ASUR. However, there is a large $\mathrm{HNO}_{3}$ value between $22-24 \mathrm{~km}$ for 31 January 2005 compared with ASUR measurement (the MLS data is not shown between $22-24 \mathrm{~km}$ here). Overall, the model simulation EXP_A captures the observed profile well, but some differences exist. For example, EXP_A underestimates $\mathrm{HNO}_{3}$ at $14 \mathrm{~km}$ (2-3 ppbv) and overestimates it around $24 \mathrm{~km}$ compared with ASUR, but matches better with MLS data. Please note the differences between ASUR and the model in $\mathrm{HNO}_{3}$ around $24 \mathrm{~km}$ are likely related to the limited resolution of the ASUR $\mathrm{HNO}_{3}$ measurement (Kleinböhl, 2011). By contrast, EXP_B using the microphysics DLAPSE denitrification scheme captures the MLS profile remarkably well. The model with the thermodynamic equilibrium PSC scheme overestimates denitrification of the lower stratosphere, while the simulation using the more detailed microphysical denitrification scheme is in excellent agreement with observed $\mathrm{HNO}_{3}$ from ASUR measurements from 15 to $20 \mathrm{~km}$, where the PSCs dominate and play important role in denitrification.

The MLS and ASUR measurements detected evidence for $\mathrm{Cl}$ activation from $\mathrm{ClO}$ and the absence of $\mathrm{HCl}$ between 16 and $22 \mathrm{~km}$ on the flights of 31 January and 5 February (the negative ASUR $\mathrm{HCl}$ values at 18 and $20 \mathrm{~km}$ and $\mathrm{ClO}$ profile comparison for 5 February are not shown here). The negative values in the ASUR $\mathrm{HCl}$ measurement are likely caused by the retrieval not quite being able to follow the steep slope from high values in the middle stratosphere to zero $\mathrm{HCl}$ in the lower stratosphere (Kleinböhl, 2011). The vertical distributions of modelled $\mathrm{HCl}$ and $\mathrm{ClO}$ in the SLIMCAT (EXP_A and EXP_B) compare quite well to ASUR and MLS below $25 \mathrm{~km}$. The modelled ozone values in the lower stratosphere at $16-18 \mathrm{~km}$ are very close to the MLS and ASUR data. However, the model underestimates ASUR observed $\mathrm{O}_{3}$ above $28 \mathrm{~km}$ but this is not the relevant region for polar stratospheric ozone depletion and agreement with MLS is better. There is still some $\mathrm{O}_{3}$ difference between EXP_A 

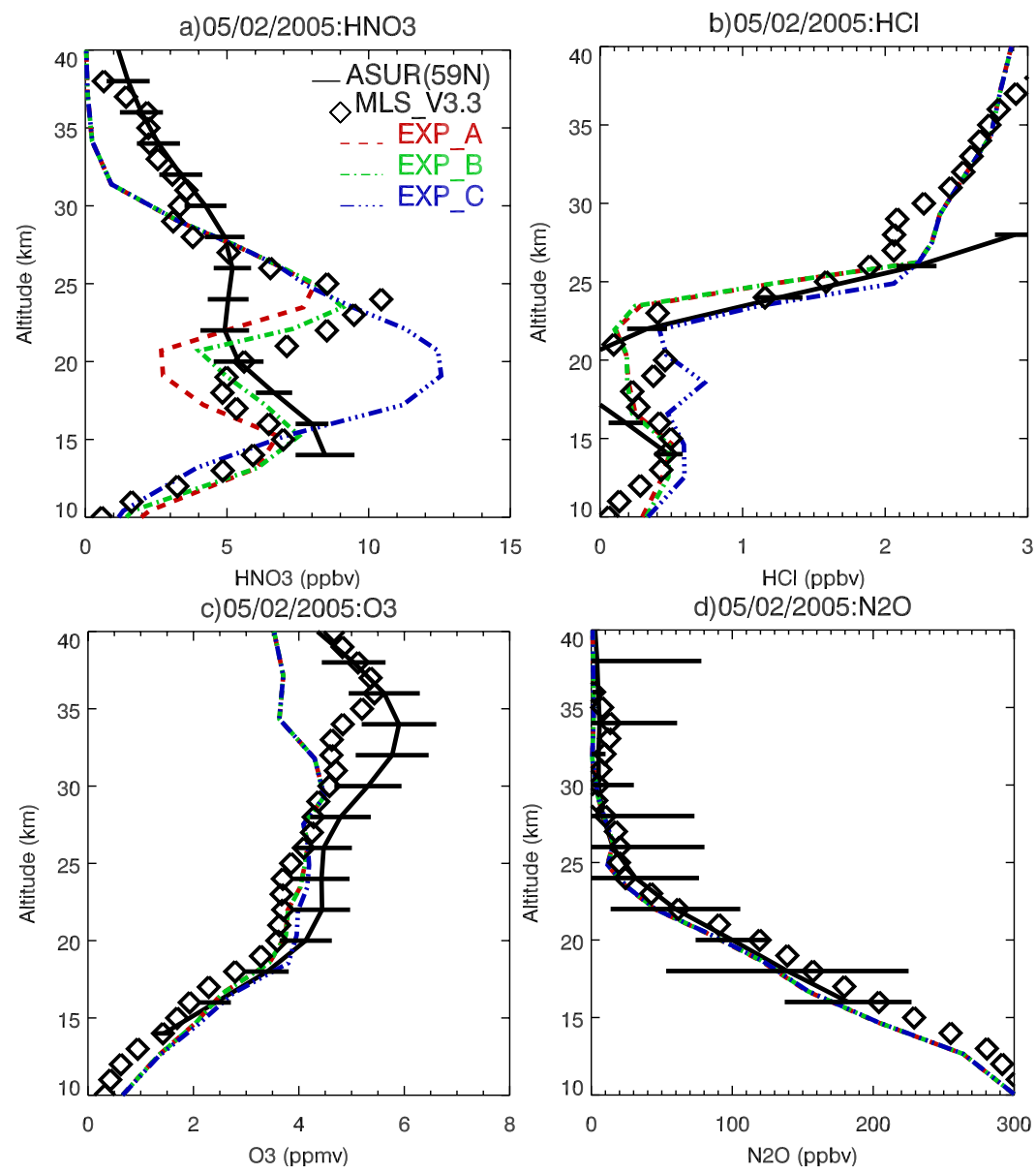

Fig. 2. $\mathrm{HNO}_{3}, \mathrm{HCl}, \mathrm{O}_{3}$ and $\mathrm{N}_{2} \mathrm{O}$ from ASUR observations and model simulations using equilibrium (EXP_A), DLAPSE (EXP_B) PSC schemes and without denitrification (EXP_C) for 5 February 2005.

and EXP_C (though it is small) at $\sim 17 \mathrm{~km}$ due to the effect of denitrification on $\mathrm{O}_{3}$ loss at this time of the year. Profiles of the long-lived species $\mathrm{N}_{2} \mathrm{O}$ can be used to verify modelled tracer transport (Feng et al., 2005a). The model has too strong descent in the lower stratosphere when compared with MLS and ASUR data for the flight on 31 January and also for the flight on 5 February.

Figure 3 shows the relative difference of profiles of $\mathrm{HNO}_{3}$ and $\mathrm{O}_{3}$ from ASUR, model simulations using two different PSC schemes (EXP_A, EXP_B) and the model run without denitrification (EXP_C) for 31 January and 5 February 2005. Again, the SLIMCAT simulation using the thermodynamic equilibrium has larger denitrification (relative difference is about $20-50 \%$ at $15-20 \mathrm{~km}$ ) than using the microphysical DLAPSE scheme (less than $10 \%$ ) which is much close to the ASUR observations. The relative $\mathrm{O}_{3}$ differences between EXP_A, EXP_B and EXP_C are quite small (less than 10\%) in the lower stratosphere though there are larger relative percent differences with observations in the lowermost and middle stratosphere.
Figure 4 shows the time series of averaged $\mathrm{HNO}_{3}, \mathrm{HCl}$, $\mathrm{ClO}, \mathrm{N}_{2} \mathrm{O}$ and $\mathrm{O}_{3}$ inside the vortex on the $456 \mathrm{~K}$ isentropic level $(\sim 17 \mathrm{~km})$ from MLS measurements and SLIMCAT simulations using the two PSC schemes (EXP_A and EXP_B) and no denitrification (EXP_C). Here the vortex is defined as the area enclosed by the $65^{\circ} \mathrm{N}$ equivalent latitude (EL) contour. Again, EXP_B, the SLIMCAT simulation with the detailed DLAPSE denitrification scheme, gives excellent agreement with observed $\mathrm{HNO}_{3}$, where the equilibrium scheme overpredicts denitrification at $456 \mathrm{~K}$. The model captures the temporal evolution of observed $\mathrm{HCl}$ and $\mathrm{ClO}$, but the model with full chemistry (EXP_A and EXP_B) seems to have too much chlorine activation from late February to mid-March 2005 which is also confirmed by Santee et al. (2008). Even though the modelled $\mathrm{HNO}_{3}$ field is significantly improved when using the DLAPSE microphysical scheme (EXP_B), the differences of the simulated $\mathrm{O}_{3}$ at 456 $\mathrm{K}$ from the SLIMCAT full chemistry experiments (EXP_A and EXP_B) are not significant, possibly because the same surface area of the liquid aerosol are used for the chlorine 

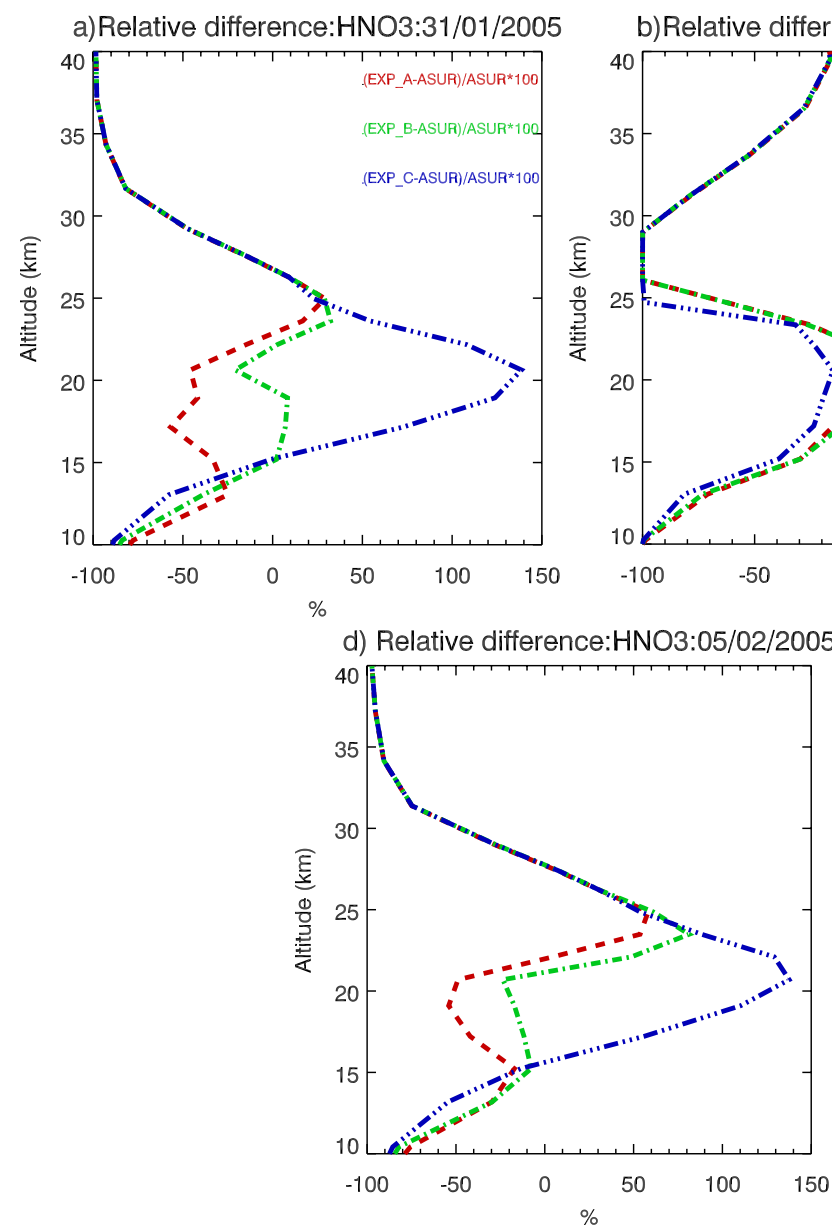
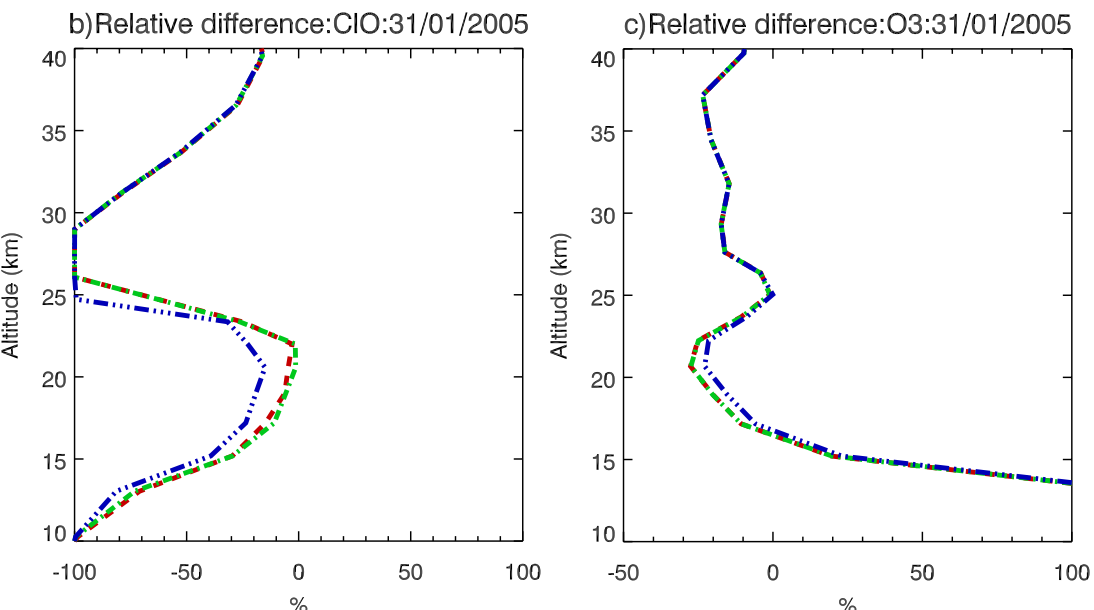

e) Relative difference:03:05/02/2005

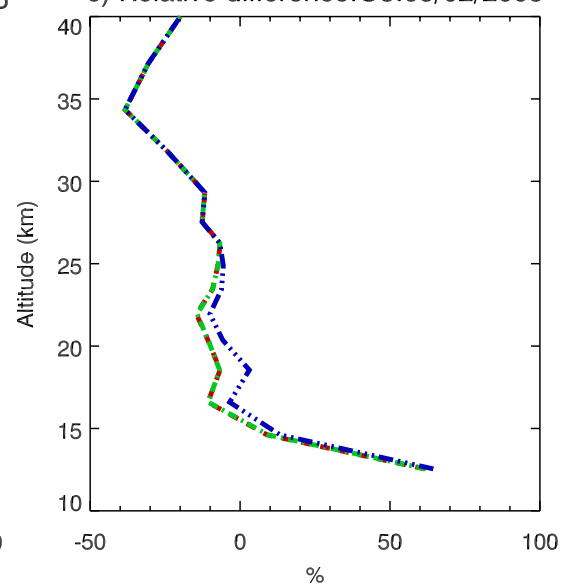

Fig. 3. The relative difference (\%) of $\mathrm{HNO}_{3}, \mathrm{ClO}$ and $\mathrm{O}_{3}$ between ASUR measurements and SLIMCAT full chemistry simulations using the equilibrium (EXP_A) and DLAPSE (EXP_B) PSC schemes and without denitrification (EXP_C) for 31 January and 5 February 2005.

activation in these two experiments (EXP_A and EXP_B). This requires further detailed investigation. Obviously, the modelled ozone overestimates the observations if denitrification is not considered in the model (EXP_C). The observed $\mathrm{N}_{2} \mathrm{O}$ values inside the vortex decreased rapidly in early December, increased in late December, then decreased again until mid January. The model captures many features of observed $\mathrm{N}_{2} \mathrm{O}$ evolution, but overall, model has more diabatic descent than MLS observations.

Figure 5 shows the vortex-averaged modelled $\mathrm{NO}_{\mathrm{y}}$ and $\mathrm{ClO}_{\mathrm{x}}\left(=\mathrm{Cl}+\mathrm{ClO}+2 \times \mathrm{Cl}_{2} \mathrm{O}_{2}\right)$ as a function of time and potential temperature for Arctic winter 2004/2005 from the three simulations. The $\mathrm{NO}_{\mathrm{y}}$ has values larger than $10 \mathrm{ppbv}$ above $450 \mathrm{~K}$ in early December but these decrease rapidly after mid December. Denitrification is predicted to have started in December and the very low ambient temperatures produce lower $\mathrm{NO}_{\mathrm{y}}$ values due to PSC formation and denitrification between 400 and $530 \mathrm{~K}(\sim 14$ to $22 \mathrm{~km}) . \mathrm{NO}_{\mathrm{y}}$ in EXP_A, using the thermodynamic equilibrium scheme, is as low as 3 ppbv by late January, indicating that extensive denitrification has occurred. As shown in Mann et al. (2002, 2003) when the cold pool is offset from the centre of rotation of the vortex, denitrification is weak due to short particle lifetimes. EXP_B, using DLAPSE scheme, captures this behaviour, but the standard SLIMCAT model based on the equilibrium scheme (EXP_A) continues to predict denitrification.

Chlorine activation on PSCs occurred at high altitudes from early December and activation gradually extended downwards even to the lowermost stratosphere (below $400 \mathrm{~K}$ ) which consistent with corresponding low temperatures and descent of air and potential PSC extent. Maximum $\mathrm{ClO}_{\mathrm{x}}$ exceeded $2.7 \mathrm{ppbv}$ from late December until early February. Modelled chlorine activation is reduced if denitrification is not considered in the model (EXP_C) as chlorine deactivation mainly occurs by the reaction of $\mathrm{ClO}+\mathrm{NO}_{2}+\mathrm{M}$ $\rightarrow \mathrm{ClONO}_{2}+\mathrm{M}$ and the time for stratospheric chlorine deactivation depends on the degree of denitrification in the Arctic. 
a) Vortex averaged HNO3:456K

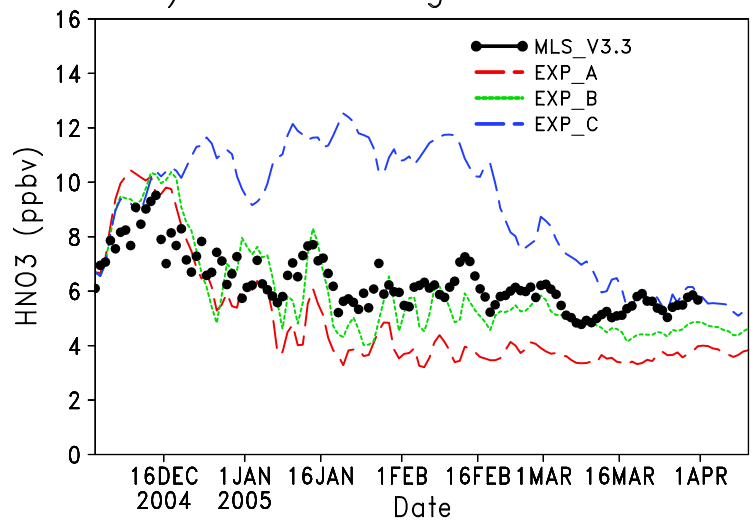

c) Vortex averaged $\mathrm{ClO}: 456 \mathrm{~K}$

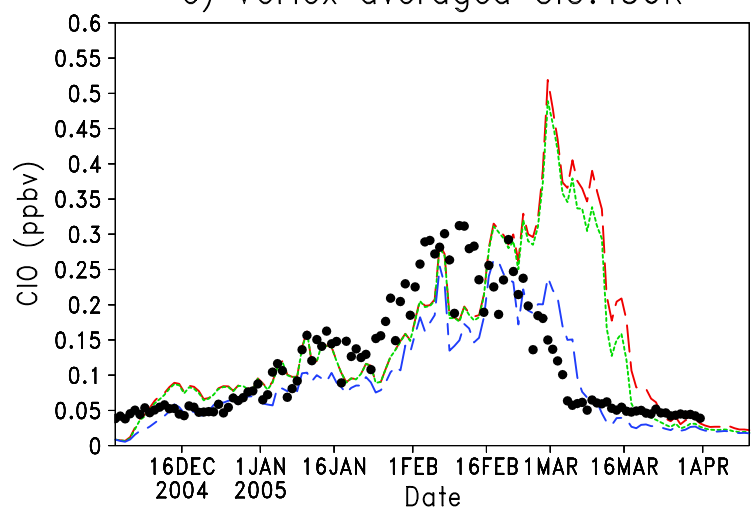

b) Vortex averaged $\mathrm{HCl}: 456 \mathrm{~K}$

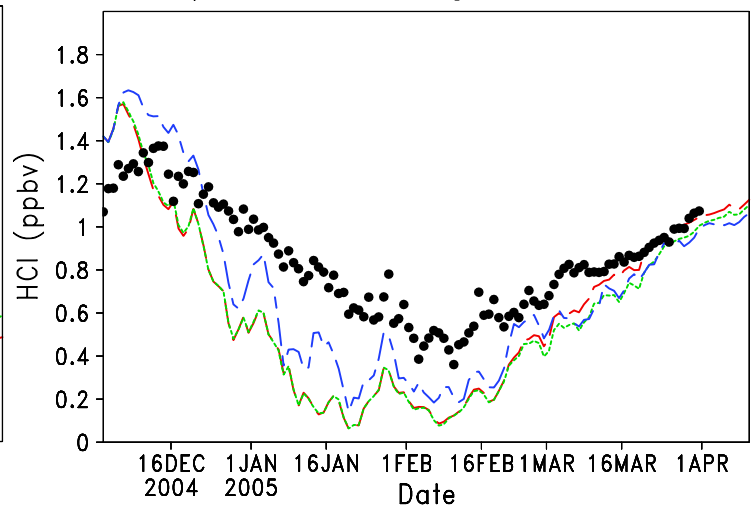

d) Vortex averaged N20:456K

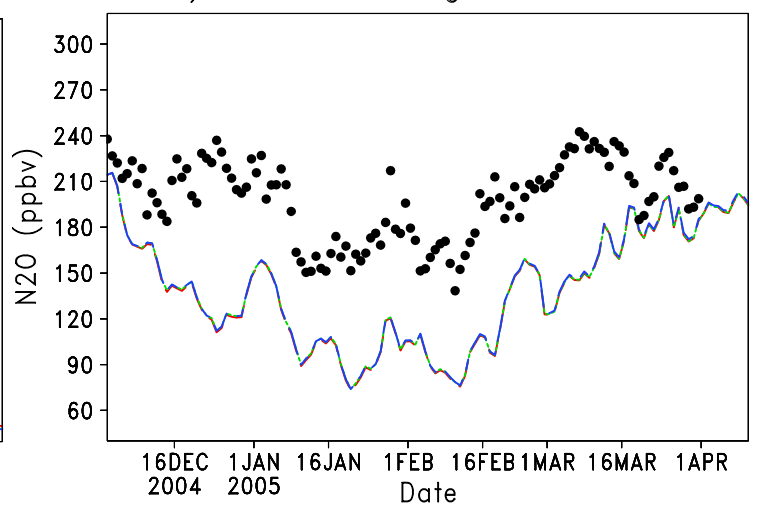

e) Vortex averaged 03:456K

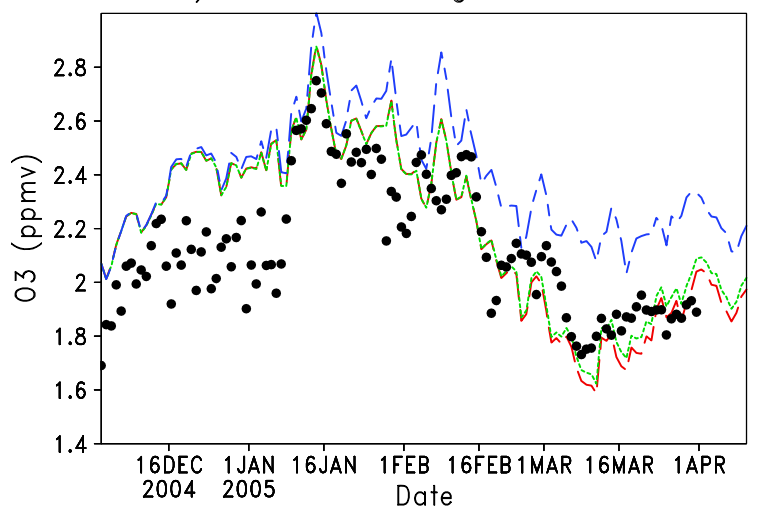

Fig. 4. Time evolution of $\mathrm{HNO}_{3}, \mathrm{HCl}, \mathrm{ClO}, \mathrm{N}_{2} \mathrm{O}$ and $\mathrm{O}_{3}$ from MLS measurements and SLIMCAT simulations using the equilibrium (EXP_A) and DLAPSE (EXP_B) PSC schemes as well as the simulation without denitrification (EXP_C) at $456 \mathrm{~K}(\sim 17 \mathrm{~km})$.

If $\mathrm{NO}_{2}$ decreases due to the removal of nitrogen reservoirs by denitrification process, chlorine deactivation will be delayed. EXP_A using the equilibrium PSC scheme has stronger denitrification than EXP_B and has a longer deactivation time and prolonged Arctic ozone loss. The deactivation is even faster if no denitrification is included in the model. The DLAPSE denitrification scheme (EXP_B) has realistic denitrification, therefore, slowing down chemical ozone depletion compared to the thermodynamical equilibrium scheme (EXP_A).

Figure 6 is the absolute difference of vortex-averaged modelled $\mathrm{NO}_{\mathrm{y}}$ and $\mathrm{ClO}_{\mathrm{x}}$ between the full chemistry simulations (EXP_A, EXP_B) and the SLIMCAT simulation without denitrification (EXP_C). Overall, the patterns of $\mathrm{NO}_{\mathrm{y}}$ and $\mathrm{ClO}_{\mathrm{x}}$ differences are very similar. Again, more extensive 
Table 2. Inferred maximum ozone loss for Arctic winter 2004/2005.

\begin{tabular}{|c|c|c|c|c|}
\hline Reference & Model/Measurement & Ozone loss & Altitude & Period \\
\hline \multirow[t]{2}{*}{ Manney et al. (2006) } & \multirow[t]{2}{*}{ EOS MLS } & $1.2-1.5 \mathrm{ppmv}$ (vortex) & $450-500 \mathrm{~K}$ & Jan-mid-Mar \\
\hline & & 2 ppmv (vortex edge) & $500 \mathrm{~K}$ & Jan-mid-Mar \\
\hline Rösevall et al. (2008) & Aura MLS & $0.9-1.3 \mathrm{ppmv}$ & $450 \mathrm{~K}$ & 1 Jan-mid-Mar \\
\hline Rösevall et al. (2008) & Odin SMR & $0.6-1.3 \mathrm{ppmv}$ & $450 \mathrm{~K}$ & 1 Jan-mid-Mar \\
\hline \multirow[t]{2}{*}{ Jin et al. (2006) } & \multirow[t]{2}{*}{ ACE-FTS } & $1.8-2.6 \mathrm{ppmv}$ & $475-500 \mathrm{~K}$ & Jan-mid-Mar \\
\hline & & 108-139 DU & Total column & Jan-mid-Mar \\
\hline \multirow[t]{2}{*}{ Rex et al. (2006) } & \multirow[t]{2}{*}{ Ozonesondes/SAGE III/POAM III } & $1.2-1.8 \mathrm{ppmv}$ & $400-450 \mathrm{~K}$ & 5 Jan-25 Mar \\
\hline & & $(121 / 110 / 113) 127 \pm 21 \mathrm{DU}$ & $380-550 \mathrm{~K}$ & 5 Jan-25 Mar \\
\hline \multirow[t]{2}{*}{ von Hobe et al. (2006) } & \multirow[t]{2}{*}{ M55 Geophysica aircraft } & $2.1-2.3 \mathrm{ppmv}$ & $380-470 \mathrm{~K}$ & Jan-7 Mar \\
\hline & & 75-103 DU & Total column & Jan-7 Mar \\
\hline \multirow[t]{2}{*}{ Tsvetkova et al. (2007) } & \multirow[t]{2}{*}{ SAGE III } & $1.7 \mathrm{ppmv}$ & $450-475 \mathrm{~K}$ & 1 Jan-25 Mar \\
\hline & & $116-128 \pm 10 \mathrm{DU}$ & Total column & 1 Jan-25 Mar \\
\hline Rösevall et al. (2008) & DIAMOND+Odin SMR & $1.0-1.1 \mathrm{ppmv}$ & $430-460 \mathrm{~K}$ & 1 Jan-mid-Mar \\
\hline Rösevall et al. (2008) & DIAMOND+Aura MLS & $0.7-0.9 \mathrm{ppmv}$ & $430-460 \mathrm{~K}$ & 1 Jan-mid-Mar \\
\hline Jackson and Orsolini (2008) & Met Office+EOS MLS/SBUV & $0.8-1.2 \mathrm{ppmv}$ & $450 \mathrm{~K}$ & Jan-early Mar \\
\hline El Amraoui et al. (2008) & $M O C A G E+$ Aura MLS & $1.5 \mathrm{ppmv}$ & $425 \mathrm{~K}$ & 10 Jan-10 Mar \\
\hline \multirow[t]{2}{*}{ Singleton et al. (2007) } & SLIMCAT/EOS MLS/POAM III & & & \\
\hline & /SAGE III/ACE-FTS/MAESTRO & $2-2.3 \mathrm{ppmv}$ & $450 \mathrm{~K}$ & Dec-mid-Mar \\
\hline \multirow[t]{2}{*}{ Kuttippurath et al. (2010) } & Mimosa-Chim/Aura MLS & $1.5-1.7 \mathrm{ppmv}$ & $475 \mathrm{~K}$ & Dec-Mar \\
\hline & & $109 \mathrm{DU}$ & $350-550 \mathrm{~K}$ & Dec-Mar \\
\hline \multirow[t]{2}{*}{ Grooß and Müller (2007) } & CLaMS & $1.08-1.66 \mathrm{ppmv}$ & $475 \mathrm{~K}$ & Jan-Mar \\
\hline & & $69 \pm 21 \mathrm{DU}$ & $380-550 \mathrm{~K}$ & Jan-Mar \\
\hline \multirow[t]{2}{*}{ Feng et al. (2007a) } & SLIMCAT:EXP_A & $2-2.3 \mathrm{ppmv}$ & $456 \mathrm{~K}$ & Dec-Mar \\
\hline & & $140 \mathrm{DU}$ & $380-550 \mathrm{~K}$ & Dec-Mar \\
\hline \multirow[t]{2}{*}{ This work } & SLIMCAT:EXP_B & $2-2.13 \mathrm{ppmv}$ & $456 \mathrm{~K}$ & Dec-Mar \\
\hline & & $130 \mathrm{DU}$ & $380-550 \mathrm{~K}$ & Dec-Mar \\
\hline \multirow[t]{2}{*}{ This work } & SLIMCAT:EXP_C & $0.6-0.8 \mathrm{ppmv}$ & $456 \mathrm{~K}$ & Dec-Mar \\
\hline & & $90 \mathrm{DU}$ & $380-550 \mathrm{~K}$ & Dec-Mar \\
\hline
\end{tabular}

denitrification has occurred in the model with the thermodynamic equilibrium scheme (EXP_A) than with a detailed microphysical denitrification scheme DLAPSE (EXP_B). There are large $\mathrm{ClO}_{\mathrm{x}}$ differences above $500 \mathrm{~K}(\sim 21 \mathrm{~km})$ before mid-February and in the lower stratosphere in late February/early March. However, the difference in $\mathrm{ClO}_{\mathrm{x}}$ is still small between EXP_A and EXP_B.

The ozone loss for Arctic winter 2004/2005 has been estimated through various methods by researchers using different measurements and/or models (e.g., Manney et al., 2006; Jin et al., 2006; Rex et al., 2006; von Hobe et al., 2006; Singleton et al., 2007; Grooß and Müller, 2007; Feng et al., 2007a; Tsvetkova et al., 2007; Rösevall et al., 2008; Jackson and Orsolini, 2008; Kuttippurath et al., 2010). However, there are large differences in the inferred maximum ozone loss. Table 2 gives the estimated/calculated Arctic ozone loss from the various measurements and/or model simulations for Arctic winter 2004/2005. For Arctic winter 2004/2005, the ozone loss inferred from Odin satellite SMR (Sub-Millimetre Radiometer) is 0.6-1.3 ppmv (Rösevall et al., 2008), which is lower than from other measurements, while the inferred ozone loss (2.1-2.3 ppmv) from M55 Geophysica aircraft data (von Hobe et al., 2006) and about 1.8-2.6 ppmv from ACE-FTS (Atmospheric Chemistry Experiment-Fourier Transform Spectrometer) measurement (Jin et al., 2006) is higher. The calculated ozone loss is $0.8-1.2$ ppmv from the assimilation of measurement data into the models (Jackson and Orsolini, 2008; Rösevall et al., 2008). El Amraoui et al. (2008) also assimilated Aura MLS $\mathrm{O}_{3}$ and $\mathrm{N}_{2} \mathrm{O}$ data into the MOCAGE CTM model and they showed a maximum of 1.5 ppmv ozone loss at $425 \mathrm{~K}$. Singleton et al. (2007) estimated 2.0-2.3 ppmv ozone loss using data from different satellite instruments and the SLIMCAT model which is similar to the estimate from Feng et al. (2007a). The calculated ozone loss is $1.08-1.66 \mathrm{ppmv}$ from the 3-D CTM CLaMS (Chemical Lagrangian Model of the Stratosphere) (Grooß and Müller, 2007). The full chemistry of SLIMCAT with the simple thermodynamical equilibrium PSC scheme (EXP_A) gives 2-2.3 ppmv ozone loss while it is slightly lower when the DLAPSE denitrification scheme used (EXP_B). Clearly, SLIMCAT without denitrification (EXP_C) has less ozone loss $(0.6-0.8$ ppmv) as expected.

Figure 7 shows time series of vortex-averaged ozone loss and maximum local ozone loss at $456 \mathrm{~K}$ and partial column ozone loss $(380-550 \mathrm{~K})$ from the three simulations (EXP_A, 

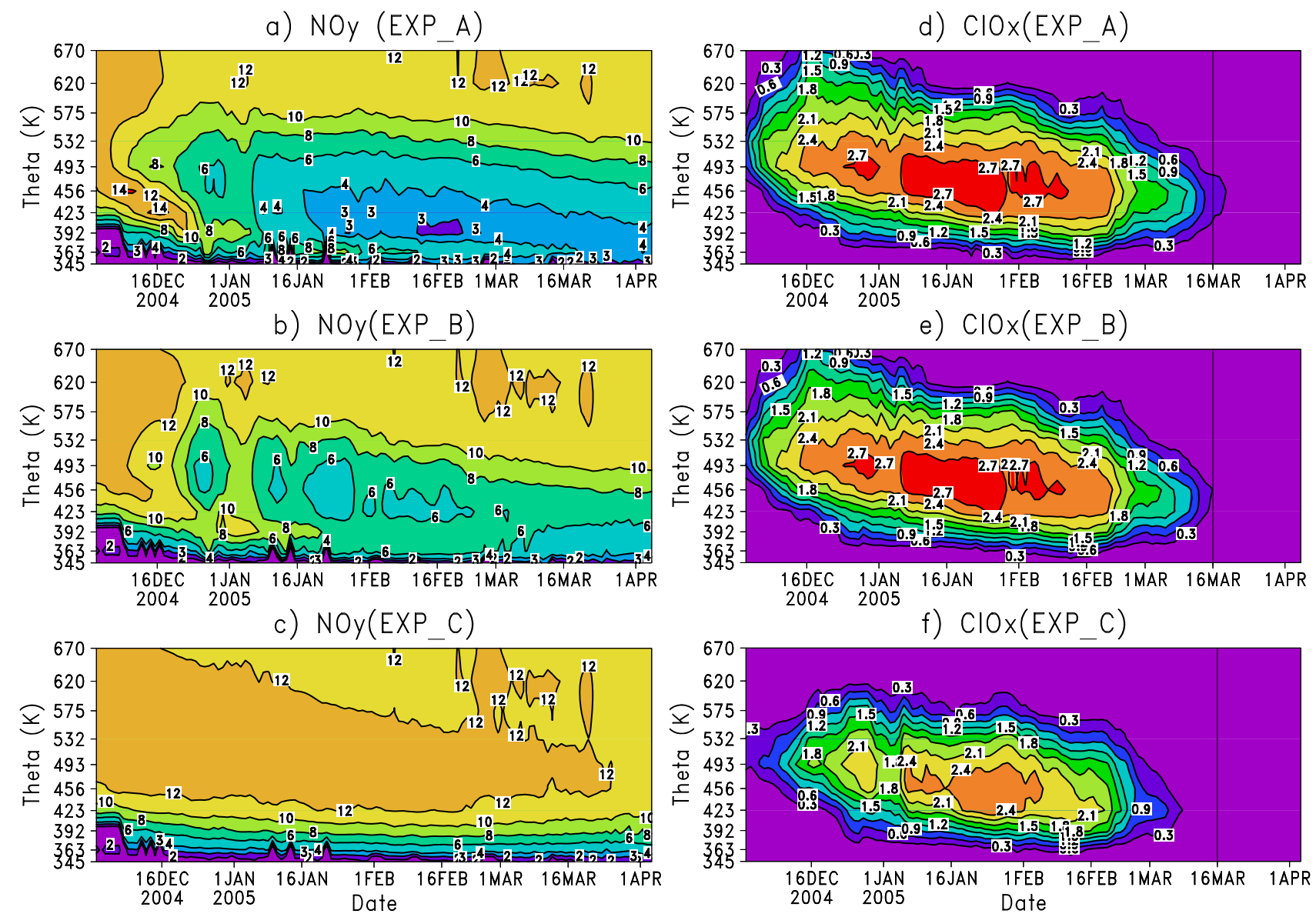

Fig. 5. Vortex-averaged $\mathrm{NO}_{\mathrm{y}}$ and $\mathrm{ClO}_{\mathrm{x}}$ (ppbv) as a function of time and potential temperature for SLIMCAT simulations using the equilibrium (EXP_A) and DLAPSE (EXP_B) PSC schemes and the simulation without denitrification (EXP_C) for Arctic winter 2004/2005.

EXP_B and EXP_C). Arctic polar ozone depletion began in December 2004 in the cold polar vortex and strong chlorine activation regions and the maximum ozone loss was reached in mid March 2005, followed by a decrease due to the vortex break-up and increased temperatures. The SLIMCAT full chemistry simulations have a similar ozone loss signal, but using the equilibrium scheme (EXP_A) has slightly higher ozone loss than EXP_B, while the ozone loss is much less for EXP_C, when denitrification is switched off. The lower stratospheric partial column ozone losses show very similar patterns. There is $\sim 90 \mathrm{DU}$ partial column ozone loss between $380-550 \mathrm{~K}$ from the model without denitrification (EXP_C), much lower than the observed $127 \pm 21$ DU by Rex et al. (2006) and inferred 109 DU ozone loss derived from Mimosa-Chim CTM and Aura MLS by Kuttippurath et al. (2010). The estimated partial column ozone from CLaMS is $69 \pm 21 \mathrm{DU}$, which is still unclear and needs further investigation (Grooß and Müller, 2007). The diagnosed partial column ozone loss from the model with the full microphysical DLAPSE scheme (EXP B) is about $130 \mathrm{DU}$ which better matches the observations (Rex et al., 2006), while the standard model based on a simple thermodynamic equilibrium PSC scheme (EXP_A) is about 140 DU, which slightly overestimates the observations (e.g., Jin et al., 2006; Rex et al., 2006; von Hobe et al., 2006; Tsvetkova et al., 2007). Figure 8 shows time series of differences in vortex-averaged ozone loss at $456 \mathrm{~K}$ and partial column ozone loss (380-550 K) between model sensitivity experiments (EXP_B, EXP_C) and standard SLIMCAT simulation (EXP_A) for Arctic winter 2004/2005. There are less ozone loss using a full microphysical DLAPSE denitrification scheme (EXP_B) than using a simple thermodynamic equilibrium PSC scheme (EXP_A) in SLIMCAT. The vortexaveraged ozone loss is small (less than $0.2 \mathrm{ppmv}$ ) between the full chemistry SLIMCAT (EXP_A and EXP_B), The partial column ozone difference is $\sim 10 \mathrm{DU}$ in late winter/early spring 2004/2005. However, there are larger ozone loss differences $(1.2-1.6 \mathrm{ppmv}$ at $456 \mathrm{~K}, 40-60 \mathrm{DU}$ partial column 

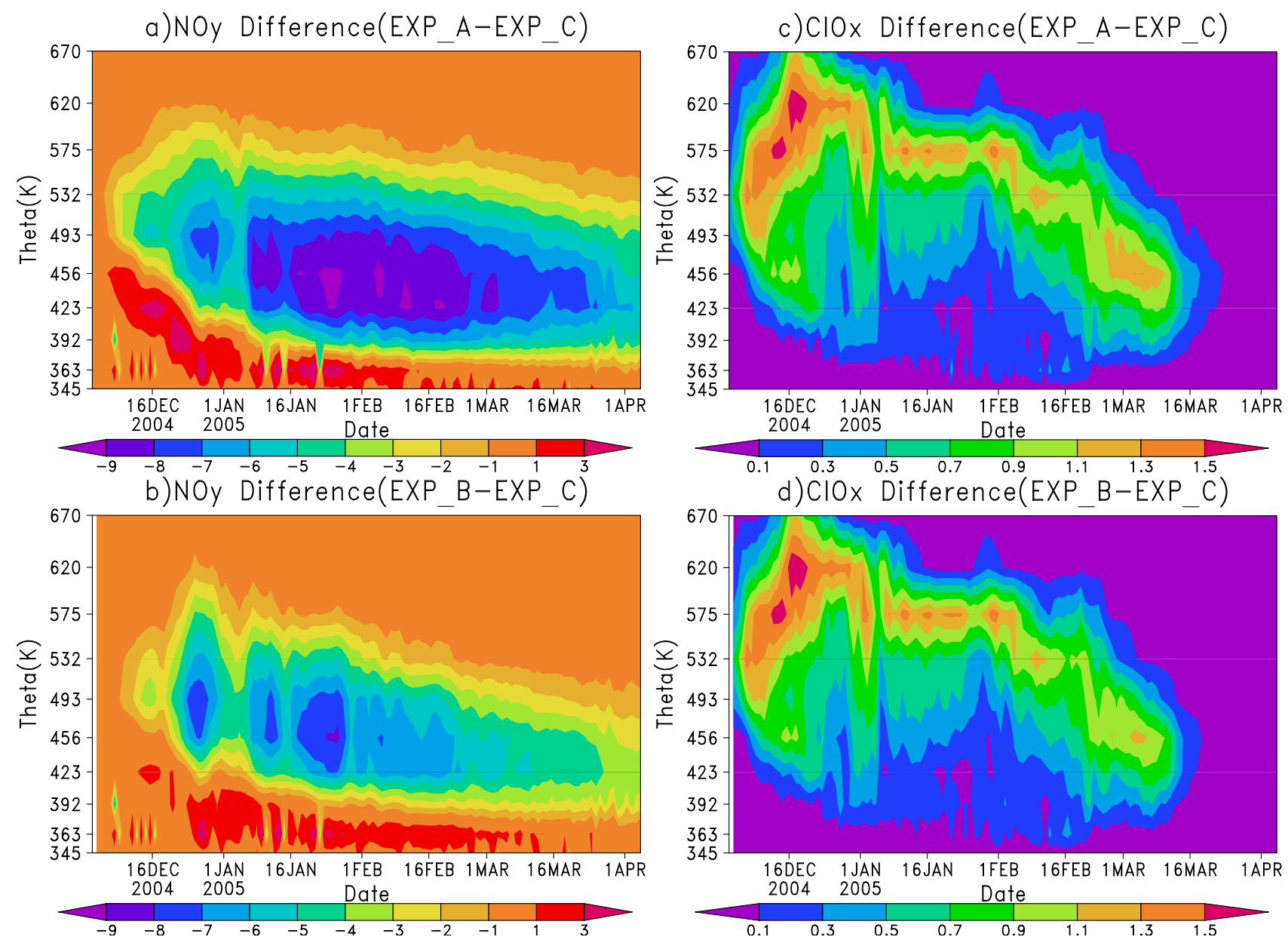

Fig. 6. Difference in vortex-averaged $\mathrm{NO}_{\mathrm{y}}$ and $\mathrm{ClO}_{\mathrm{x}}$ (ppbv) as a function of time and potential temperature for SLIMCAT full chemistry simulations using the equilibrium (EXP_A) and DLAPSE (EXP_B) PSC schemes with respect to the SLIMCAT simulation without denitrification (EXP_C) for Arctic winter 2004/2005.

ozone loss between $380-550 \mathrm{~K}$ ) if denitrification is not considered in the model. This clearly shows the importance of considering denitrification in the model and emphasises the importance of denitrification for Arctic ozone depletion.

\section{Conclusions}

We have used a three-dimensional (3-D) chemical transport model SLIMCAT to quantify the effect of denitrification on ozone loss for the Arctic winter 2004/2005. This is an extension of work from Feng et al. (2007a). The standard SLIMCAT full chemistry model, when using a thermodynamic equilibrium PSC scheme, overestimates Arctic ozone loss for winter 2004/2005 due to too strong chlorine activation and the overestimation of denitrification. The model simulation using the microphysical denitrification scheme DLAPSE successfully reproduces the observed $\mathrm{HNO}_{3}$ as measured by the ASUR and Aura MLS instruments. Kleinböhl et al. (2005) and Schoeberl et al. (2006) also used ASUR and MLS measurements to study the denitrification for Arctic winter 2004/2005. Kleinböhl et al.(2005) showed that the observed $\mathrm{HNO}_{3}$ deficit from ASUR measurement in January/February 2005 is about $6 \mathrm{ppbv}$ at $475 \mathrm{~K}$. Schoeberl et al. (2006) also confirmed that there is large $\mathrm{HNO}_{3}$ decrease in late January 2005 and the net $\mathrm{HNO}_{3}$ changes are roughly corresponding with the coldest temperature based on Aura MLS measurements. Manney et al. (2003), Goutail et al. (2005) and Feng et al. (2007a) have shown large year-to-year variations of polar Arctic ozone loss due to different meteorological conditions. There have been extensive studies about denitrification for cold Arctic winters (e.g., Carslaw et al., 2002; Davies et al., 2002; Grooß et al., 2002; Kleinböhl, 2004; Kleinböhl et al., 2005; Jin et al., 2006; Davies et al., 2006; Schoeberl et al., 2006). Some of these studies also included the SLIMCAT model run with the equilibrium denitrification 


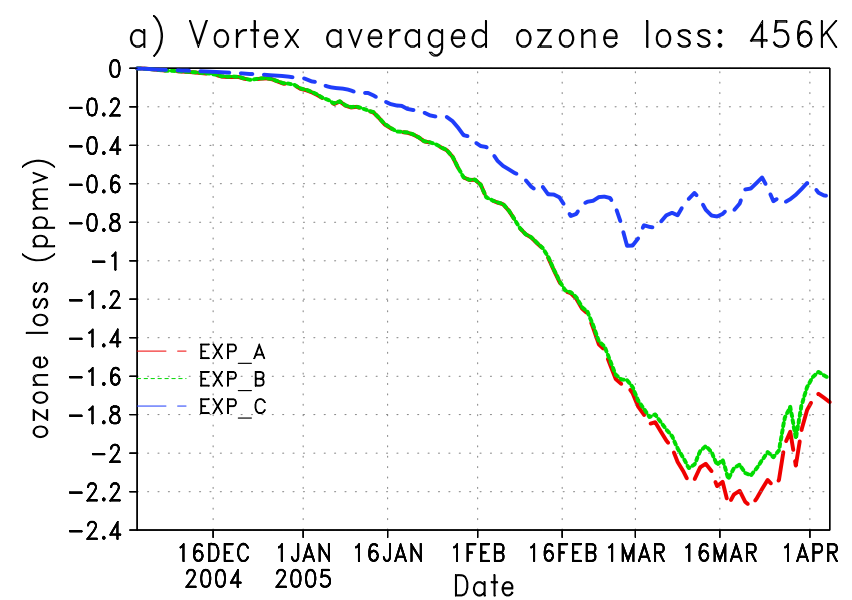

b) Maximum Ozone Loss(\%): $456 \mathrm{~K}$
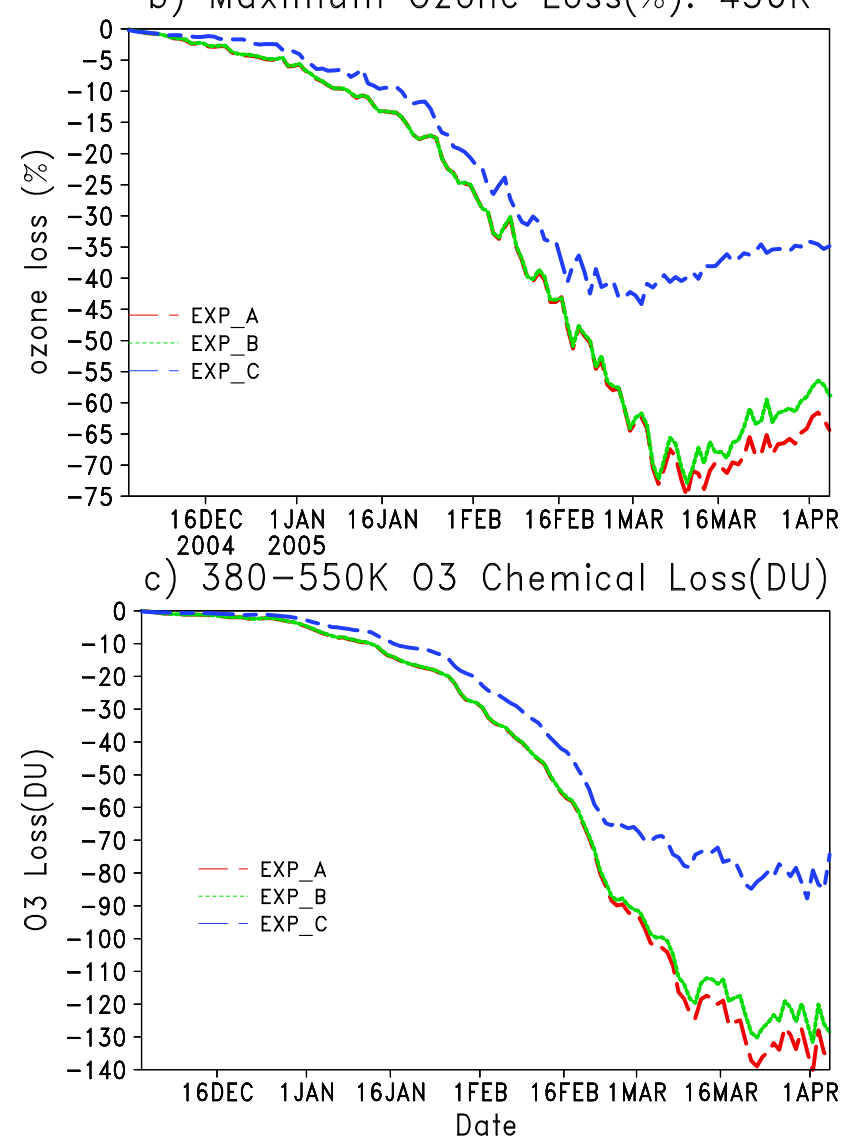

Fig. 7. Time series of (a) vortex-averaged ozone loss, (b) maximum local ozone loss at $456 \mathrm{~K}(\sim 17 \mathrm{~km})$ and (c) partial column ozone loss between $380-550 \mathrm{~K}(\sim 13-23 \mathrm{~km})$ from simulations EXP_A and EXP_B and EXP_C for Arctic winter 2004/2005.

scheme or DLAPSE schemes. The results showed that the model using the DLAPSE microphysical denitrification scheme is able to produce denitrification and in good agreement with observations for the previous Arctic winters (e.g., 1999/2000, 2003/04). The simulation from the model run
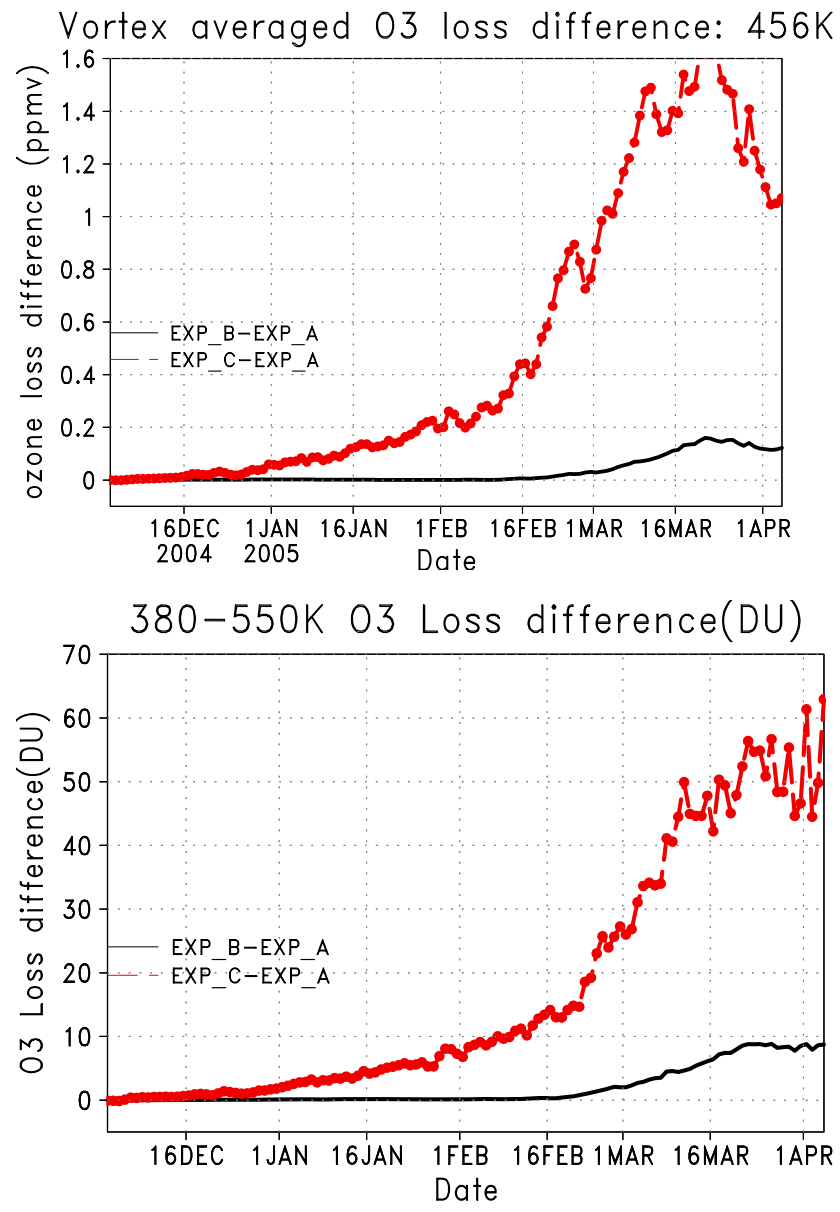

Fig. 8. Time series of differences in (a) vortex-averaged ozone loss ozone loss at $456 \mathrm{~K}(\sim 17 \mathrm{~km})$ and (b) partial column ozone loss between $380-550 \mathrm{~K}(\sim 13-23 \mathrm{~km})$ between model sensitivity experiments (EXP_B, EXP_C) and standard SLIMCAT simulation (EXP_A) for Arctic winter 2004/2005.

without denitrification process (EXP_C) underestimates the Arctic polar ozone depletion by $\sim 30 \%$, i.e. $40-60 \mathrm{DU}$ partial column ozone loss for Arctic winter 2004/2005, which is slightly larger than the inferred contribution of denitrification of polar ozone loss for previous Arctic winters. For example, Davies et al. (2002) showed that denitrification induced extra 21-30\% maximum ozone loss at $460 \mathrm{~K}$ for Arctic winter 1999/2000 using SLIMCAT model. Grooß et al. (2002) also used the Lagrangian CTM model CLaMS to study the ozone depletion in spring 2000 and they showed that the denitrification had strong chlorine deactivation and ozone depletion starting in March 2000. The enhanced ozone loss due to the denitrification was $0.3 \mathrm{ppmv}$ (about $18 \%$ ) at $450 \mathrm{~K}$ from 10 Feburary to 20 March 2000. Tripathi et al. (2010) estimated the contributions of denitrification on Arctic ozone loss were about $23 \%$ for Arctic winter 1999/2000 and $17 \%$ for Arctic winter 2002/2003 using the high resolution CTM MIMOSACHIM model. 
The time taken for stratospheric chlorine deactivation depends crucially on the degree of denitrification. Therefore, accurately simulating the impact of denitrification on Arctic ozone depletion requires a detailed microphysical PSC scheme in the model. The simulations are quite sensitive to the PSC schemes used in the model, with about $\sim 5-10 \%$ at $\sim 17 \mathrm{~km}$ effect on Arctic ozone loss when using the simple equilibrium or the microphysical PSC scheme.

Atmospheric chemistry models, i.e., chemistry climate models (CCMs) and chemical transport models (CTMs), are now widely used to predict future stratospheric ozone change. However, most CCMs and CTMs are still using simple thermodynamic equilibrium PSC schemes for the determination of heterogeneous chemistry and denitrification (e.g., SPARC CCMval., 2010). Many studies have shown that an increased severity of denitrification may delay the recovery of polar ozone in spring (e.g., Rex et al., 1997; Waibel et al., 1999; Esler and Waugh, 2002; Davies et al., 2002). In this paper, we have shown that using the microphysical denitrification scheme in SLIMCAT improves the $\mathrm{HNO}_{3}$ simulation and partial column ozone depletion compared with measurements. Therefore, it would be very important to consider a full microphysical denitrification process in CCMs and CTMs for better simulations or predictions of current/future polar ozone trends in Arctic polar region.

Acknowledgements. This work was supported by the EU SCOUT$\mathrm{O} 3$ and UK Natural Environment Research Council (NERC) National Centre for Earth Observation (NCEO). The ECMWF analyses were obtained via the British Atmospheric Data Centre. ASUR data is available from NASA Polar Aura Validation Experiment (PAVE). We would like to thank two reviewers and A. Kleinböhl for their time and valuable suggestions which improved the quality of this paper. Work at the Jet Propulsion Laboratory, California Institute of Technology, was done under contract with the National Aeronautics and Space Administration.

Edited by: F. Khosrawi

\section{References}

Bremer, H., von König, M., Kleinböhl, A., Küllmann, H., Künzi, K., Bramstedt, K., Burrows, J. P., Eichmann, K. U., Weber, M., and Goede A. P. H.: Ozone depletion observed by the Airborne Submillimeter Radiometer (ASUR) during the Arctic winter 1999/2000, J. Geophys. Res., 107(D20), 8277, doi:10.1029/2001JD000546, 2002.

Briegleb, B. P.: Delta-Eddington approximation for solar radiation in the NCAR community climate model, J. Geophys. Res., 97, 7603-7612, 1992.

Becker, G., Müller, R., Mckenna, D. S., Rex, M. and Carslaw, K. S.: Ozone loss rates in the Arctic stratosphere in the winter 1991/92: Model calculations compared with match results, Geophys. Res. Lett., 25, 4325-4328, doi:10.1029/1998GL900148, 1998.

Burkholder, J. B., Orlando, J. J., and Howard, C. J.: Ultravioletabsorption cross-sections of $\mathrm{Cl}_{2} \mathrm{O}_{2}$ between 210 and $410 \mathrm{~nm}, \mathrm{~J}$. Phys. Chem., 94, 687-695, 1990.
Carslaw, K. S., Kettleborough, J. A., Northway, M. J., Davies, S., Gao, R. S., Fahey, D. W., Baumgardner, D. G., Chipperfield, M. P., and Kleinböhl, A.: A vortex-scale simulation of the growth and sedimentation of large nitric acid hydrate particles, J. Geophys. Res., 107, 8300, doi:10.1029/2001JD000467, 2002.

Chipperfield, M. P.: Multiannual simulations with a threedimensional chemical transport model, J. Geophys. Res., 104, 1781-1805, 1999.

Chipperfield, M. P.: New version of the TOMCAT/SLIMCAT offline chemical transport model: Intercomparison of stratospheric tracer experiments, Q. J. Roy. Meteorol. Soc., 132, 1179-1203, doi:10.1256/qj.05.51, 2006.

Chipperfield, M. P., Feng, W., and Rex, M.: Arctic ozone loss and climate sensitivity: Updated three-dimensional model study, Geophys. Res. Lett., 32, L11813, doi:10.1029/2005GL022674, 2005.

Davies, S.: Denitrification and ozone loss in the Arctic stratosphere, PhD dissertation, University of Leeds, Leeds, UK, 191 pp., 2003.

Davies, S., Chipperfield, M. P., Carslaw, K. S., Sinnhuber, B.-M., Anderson, J. G., Stimpfle, R. M., Wilmouth, D. M., Fahey, D. W., Popp, P. J., Richard, E. C., von der Gathen, P., Jost, H., and Webster, C. R.: Modeling the effect of denitrification on Arctic ozone depletion during winter 1999/2000, J. Geophys. Res., 107, 8322, doi:10.1029/2001JD000445, 2002.

Davies, S., Mann, G. W., Carslaw, K. S., Chipperfield, M. P., Remedios, J. J., Allen, G., Waterfall, A. M., Spang, R., and Toon, G. C.: Testing our understanding of Arctic denitrification using MIPAS-E satellite measurements in winter 2002/2003, Atmos. Chem. Phys., 6, 3149-3161, doi:10.5194/acp-6-3149-2006, 2006.

Dufour, G., Payan, S., Lefévre, F., Eremenko, M., Butz, A., Jeseck, P., Té, Y., Pfeilsticker, K., and Camy-Peyret, C.: 4-D comparison method to study the NOy partitioning in summer polar stratosphere - Influence of aerosol burden, Atmos. Chem. Phys., 5, 919-926, doi:10.5194/acp-5-919-2005, 2005.

El Amraoui, L., Semane, N., Peuch, V. H., and Santee, M. L.: Investigation of dynamical processes in the polar stratospheric vortex during the unusually cold winter 2004/2005, Geophys. Res. Lett., 35, L03803, doi:10.1029/2007GL031251, 2008.

Esler, J. G. and Waugh, D. W.: A method for estimating the extent of denitrification of Arctic polar vortex air from tracer-tracer scatter plots, J. Geophys. Res., 107, 4169, doi:10.1029/2001JD001071, 2002.

Fahey, D. W., Solomon, S., Kawa, S. R., Loewenstein, M., Podolske, J. R., Strahan, S. E., and Chan, K. R.: A diagnostic for denitrification in the winter polar stratospheres, Nature, 345, 698-702, 1990.

Feng, W.: Fast ozone loss around the polar vortex during 2002/2003 Arctic winter deep minihole event, Water Air Soil Pollut., 171, 383-397, 2006.

Feng, W., Chipperfield, M. P., Davies, S., Sen, B., Toon, G., Blavier, J. F., Webster, C. R., Volk, C. M., Ulanovsky, A., Ravegnani, F., von der Gathen, P., Jost, H., Richard, E. C., and Claude, H.: Three-dimensional model study of the Arctic ozone loss in 2002/2003 and comparison with 1999/2000 and 2003/2004, Atmos. Chem. Phys., 5, 139-152, doi:10.5194/acp-5-139-2005, 2005a.

Feng, W., Chipperfield, M. P., Roscoe, H. K., Remedios, J. J., Waterfall, A. M., Stiller, G. P., Glatthor, N., Hopfner, M., and Wang, 
D.-Y.: Three-dimensional model study of the Antarctic ozone hole in 2002 and comparison with 2000, J. Atmos. Sci., 62, 822$837,2005 b$.

Feng, W., Chipperfield, M. P., Davies, S., von der Gathen, P., Kyrö, E., Volk, C. M., Ulanovsky, A., and Belyaev, G.: Large chemical ozone loss in 2004/2005 Arctic winter/spring, Geophys. Res. Lett., 34, L09803, doi:10.1029/2006GL029098, 2007a.

Feng, W., Chipperfield, M. P., Dorf, M., Pfeilsticker, K., and Ricaud, P.: Mid-latitude ozone changes: studies with a 3-D CTM forced by ERA-40 analyses, Atmos. Chem. Phys., 7, 2357-2369, doi:10.5194/acp-7-2357-2007, 2007b.

Goutail, F., Pommereau, J.-P., Lefèvre, F., van Roozendael, M., Andersen, S. B., Kastad Høiskar, B.-A., Dorokhov, V., Kyrö, E., Chipperfield, M. P., and Feng, W.: Early unusual ozone loss during the Arctic winter 2002/2003 compared to other winters, Atmos. Chem. Phys., 5, 665-677, doi:10.5194/acp-5-665-2005, 2005.

Grooß, J.-U., Günther, G.,Konopka, P., Müller, R., McKenna, D. S., Stroh, F., Vogel, B., Engel, A., Müller, M., Hoppel, K., Bevilacqua, R., Richard, E., Webster, C. R., Elkins, J. W., Hurst, D. F., Romashkin, P. A., and Baumgardner, D. G.: Simulation of ozone depletion in spring 2000 with the Chemical Lagrangian Model of the Stratosphere (CLaMS), J. Geophys. Res., 107(D20), 8295, doi:10.1029/2001JD000456, 2002.

Grooß, J.-U. and Müller, R.: Simulation of ozone loss in Arctic winter 2004/2005, Geophys. Res. Lett., 34, L05804, doi:10.1029/2006GL028901, 2007.

Jin, J. J., Semeniuk, K., Manney, G. L., Jonsson, A. I., Beagley, S. R., McConnell, J. C., Dufour, G., Nassar, R., Boone, C. E., Walker, K. A., Bernath, P. F., and Rinsland, C. P.: Severe Arctic ozone loss in the winter 2004/2005: Observations from ACE-FTS, Geophys. Res. Lett., 33, L15801, doi:10.1029/2006GL026752, 2006.

Kleinböhl, A.: Airborne submillimeter measurements of Arctic middle atmospheric trace gases: Evidence for denitrification in the Arctic polar stratosphere, Ph.D thesis, Logos Verlag, Berlin, Germany, 168 pp., 2004.

Kleinböhl, A.: Interactive comment on "Modelling the effect of denitrification on polar ozone depletion for Arctic winter/spring 2004/2005" by W. Feng et al., Atmos. Chem. Phys. Discuss., 11, C1351-C1353, 2011.

Kleinböhl, A., Bremer, H., von König, M., Küllmann, H., Kz”unzi, K., Goede, A. P. H., Browell, E. V., Grant, W. B., Toon, G. C., Blumenstock, T., Galle, B., Sinnhuber, B. M., and Davies, S., Vortex-wide denitrification of the Arctic polar stratosphere in winter 1999/2000 determined by remote observations, J. Geophys. Res., 107, 8305, doi:10.1029/2001JD001042, 2002.

Kleinböhl A., Bremer, H., Küllmann, H., Kuttippurath, J., Browell, E. V., Canty, T., Salawitch, R. J., Toon, G. C., and Notholt, J.: Denitrification in the Arctic mid-winter 2004/2005 observed by Airborne SUbmillimeter Radiometry, Geophys. Res. Lett., 32, L19811, doi:10.1029/2005GL023408, 2005.

Kühl, S., Wilms-Grabe, W., Beirle, S., Frankenberg, C., Grzegorski, M., Hollwedel, J., Khokhar, F., Kraus, S., Platt, U., Sanghavi, S., von Friedeburg, C., and Wagner, T.: Stratospheric chlorine activation in the Arctic winters 1995/96-2001/02 derived from GOME OClO measurements, Adv. Space Res., 34, 798-803, 2004.

Küllmann, H., Bremer, H., König, M., Künzi, K., Goede, A. R. W.,
Kleipool, Q. L., and Hetzheim, H.: The ASUR Sensor: A state-of the art remote sensing instrument for stratospheric trace gas measurements, Air pollution research report 73, Proceedings Fifth European Symposium on Stratospheric Ozone, 699-702, 1999.

Kuttippurath, J., Kleinböhl, A., Bremer, H., Küllmann, H., von Savigny, C., and Notholt, J.: Validation of SCIAMACHY ozone limb profiles by ASUR, Proceedings of the second workshop on the atmospheric chemistry validation of ENVISAT(ACVE-2), ESAESRIN, Frascati, Italy, 3-7 May 2004, 2004.

Kuttippurath, J., Bremer, H., Burrows, J., Kleinböhl, Küllmann, H., Künzi, K., Notholt, J., Sinnhuber, M., von Savigny, C., Lautiè, N., Murtagh, D., Urban, J., Milz, M., Stiller, G., Petelina, S., de La Noë, J., iLe Flochmoën, and Ricaud, P.: Intercomparison of ozone profile measurements from ASUR, SCIAMACHY, MIPAS, OSIRIS, and SMR, J. Geophys. Res., 112, D09311, doi:10.1029/2006JD007830, 2007.

Kuttippurath, J., Godin-Beekmann, S., Lefévre, F., and Goutail, F.: Spatial, temporal, and vertical variability of polar stratospheric ozone loss in the Arctic winters 2004/2005-2009/2010, Atmos. Chem. Phys., 10, 9915-9930, doi:10.5194/acp-10-9915-2010, 2010.

Kuttippurath, J., Kleinböhl, A., Bremer, H., Küllmann, H., Notholt, J., Sinnhuber, B. M., Feng, W., and Chipperfield, M. P.: Airborne submillimeter measurements of stratospheric $\mathrm{O}_{3}$ and $\mathrm{N}_{2} \mathrm{O}$ from the tropics to the Arctic: Comparison with models, J. Atmos. Chem., doi:10.1007/s10874-011-9191-4, 2011.

Jackson, D. R. and Orsolini, Y. J.: Estimation of Arctic ozone loss in winter 2004/2005 based on assimilation of EOS MLS and SBUV/2 observations, Q. J. Roy. Meteorol. Soc., 134, 1833$1841,2008$.

Livesey, N. J., Synder, W. V., Read, W. G., and Wagner, P. A.: Retrieval algorithms for the EOS Microwave Limb Sounder (MLS), IEEE T. Geosci. Remote, 44, 1144-1155, 2006.

Livesey, N. J., Read, W. G., Froidevaux, L., Lambert, A., Manney, G. L., Pumphrey, H. C., Santee, M. L., Schwartz, M. J., Wang, S., Cofield, R. E., Cuddy, D. T., Fuller, R. A., Jarnot, R. F., Jiang, J. H., Knosp, B. W., Stek., P. C., Wagner, P. A., and Wu., D. L.: Earth Observing System (EOS) Aura Microwave Limb Sounder (MLS) version 3.3 level 2 data quality and description document, JPL D-33509, Jet Propulsion Laboratory, California Institute of Technology, Pasadena, California, USA, 162 pp., 2011.

Mann G. W., Davies, S., Carslaw, K. S., Chipperfield, M. P., and Kettleborough, J.: Polar vortex concentricity as a controlling factor in Arctic denitrification, J. Geophys. Res., 107, 4663, doi:10.1029/2002JD002102, 2002.

Mann, G. W., Davies, S., Carslaw, K. S., and Chipperfield, M. P.: Factors controlling Arctic denitrification in cold winters of the 1990s, Atmos. Chem. Phys., 3, 403-416, doi:10.5194/acp-3403-2003, 2003.

Mann G. W., Carslaw, K. S., Chipperfield, M. P., Davies, S., and Eckermann, S. D.: Large nitric acid trihydrate particles and denitrification caused by mountain waves in the Arctic stratosphere, J. Geophys. Res., 110, D08202, doi:10.1029/2004JD005271, 2005.

Manney, G. L., Froidevaux, L., Santee, M. L., Livesey, N. J., Sabutis, J. L., and Waters, J. W.: Variability of ozone loss during Arctic winter (1991-2000) estimated from UARS Microwave Limb Sounder measurements, J. Geophys. Res., 108, 4149, doi:10.1029/2002JD002634, 2003. 
Manney, G. L., Santee, M. L., Froidevaux, L., Hoppel, K., Livesey, N. J., and Waters, J. W., EOS MLS observations of ozone loss in the 2004-2005 Arctic winter, Geophys. Res. Lett., 33, L04802, doi:10.1029/2005GL024494, 2006.

Monge-Sanz, B., Chipperfield, M. P., Simmons, A., and Uppal., S.: Mean age of air and transport in a CTM: Comparison of different ECMWF analyses, Geophys. Res. Lett., 34, L04801, doi:10.1029/2006GL028515, 2007.

Papanastasiou, D. K., Papadimitriou, V. C., Fahey, D. W., and Burkholder, J. B.: UV absorption spectrum of the $\mathrm{ClO}$ dimer $\left(\mathrm{Cl}_{2} \mathrm{O}_{2}\right)$ between 200 and $420 \mathrm{~nm}$, J. Phys. Chem., 113, 1371113726, doi:10.1021/jp9065345, 2009.

Prather, M. J.: Numerical advection by conservation of secondorder moments, J. Geophys. Res., 91, 6671-6681, 1986.

Rex, M., Harris, N. R. P., von der Gathen, P., et al., Prolonged stratospheric ozone loss in the 1995-96 Arctic winter, Nature, 389, 835-837, 1997.

Rex, M., Salawitch, R. J., von der Gathen, P., Harris, N. R. P., Chipperfield, M. P., and Naujokat, B.: Arctic ozone loss and climate change, Geophys. Res. Lett., 31, L04116, doi:10.1029/2003GL018844, 2004.

Rex, M., Salawitch, R. J., Deckelmann, H., von der Gathen, P., Harris, N. R.P., Chipperfield, M. P., Naujokat, B., Reimer, E., Allaart, M., Andersen, S. B., Bevilacqua, R., Braathen, G. O., Claude, H., Davies, J., De Backer, H., Dier, H., Dorokhov, V., Fast, H., Gerding, M., Godin-Beekmann, S., Hoppel, K., Johnson, B., Kyrö, E., Litynska, Z., Moore, D., Nakane, H., Parrondo, M. C., Risley, A. D., Skrivankova, P., Stübi, R., Viatte, P., Yushkov, V., and Zerefos, C.: Arctic winter 2005: Implications for stratospheric ozone loss and climate change, Geophys. Res. Lett., 33, L23808, doi:10.1029/2006GL026731, 2006.

Rösevall, J., Murtagh, D. P., Urban, J., Feng, W., Eriksson, P., and Brohede, S.: A study of ozone depletion in the 2004/2005 Arctic winter based on data from Odin/SMR and Aura/MLS, J. Geophys. Res., 113, D13301, doi:10.1029/2007JD009560, 2008.

Sander, S. P., Ravishankara, A. R., Friedl, R. R., Golden, D. M., Kolb, C. E., Kurylo, M. J., Molina, M. J., Huie, R. E., Orkin, V. L., Moortgat, G. K., and Finlayson-Pitts, B. J.: Chemical kinetics and photochemical data for use in stratospheric modeling, Update to Evaluation no. 14, JPL Publ., 02-25, 2006.

Santee, M. L., Lambert, A., Read, W. G., Livesey, N. J., Cofield, R. E., Cuddy, D. Y., Daffer, W. H., Drouin, B. J., Froidevaux, L., Fuller, R. A., Jarnot, R. F., Knosp, B. W., Manney, G. L., Perun, V. S., Snyder, W. V., Stek, P. C., Thurstans, R. P., Wagner, P. A., Waters, J. W., Muscari, G., de Zafra, R. L., Dibb, J. E., Fahey, D. W., Popp, P. J., Marcy, T. P., Jucks, K. W., Toon, G. C., Stachnik, R. A., Bernath, P. F., Boone, C. D., Walker, K. A., Urban, J., and Murtagh, D.: Validation of Aura Microwave Limb Sounder $\mathrm{HNO}_{3}$ measurements, J. Geophys. Res., 112, D24S40, doi:10.1029/2007JD008721, 2007.

Santee, M. L., MacKenzie, I. A., Manney, G. L., Chipperfield, M. P., Bernath, P. F., Walker, K. A., Boone, C. D., Froidevaux, L., Livesey, N. J., and Waters, J. W.: A study of stratospheric chlorine partitioning based on new satellite measurements and modeling, J. Geophys. Res., 113, D12307, doi:10.1029/2007JD009057, 2008.

Schoeberl, M. R., Kawa, S. R., Douglass, A. R., McGee, T. J., Browell, E. V., Waters, J., Livesey, N., Read, W., Froidevaux, L., Santee, M. L., Pumphrey, H. C., Lait, L. R., and Twigg, L.:
Chemical observations of a polar vortex intrusion, J. Geophys. Res., 111, D20306, doi:10.1029/2006JD007134, 2006.

Sen, B., Toon, G. C., Osterman, G. B., Blavier, J. F., Margitan, J. J., Salawitch, R. J., and Yue, G. K.: Measurements of reactive nitrogen in the stratosphere, J. Geophys. Res., 103, 3571-3585, 1998.

Singleton, C. S., Randall, C. E., Chipperfield, M. P., Davies, S., Feng, W., Bevilacqua, R. M., Hoppel, K. W., Fromm, M. D., Manney, G. L., and Harvey, V. L.: 2002-2003 Arctic ozone loss deduced from POAM III satellite observations and the SLIMCAT chemical transport model, Atmos. Chem. Phys., 5, 597609, doi:10.5194/acp-5-597-2005, 2005.

Singleton, C. S., Randall, C. E., Harvey, V. L., Chipperfield, M. P., Feng, W., Manney, G. L., Froidevaux, L., Boone, C. D., Bernath, P. F., Walker, K. A., McElroy, C. T., and Joppel, K. W.: Quantifying Arctic ozone loss during the 2004-2005 winter using satellite observations and a chemical transport model, J. Geophys. Res., 112, D07304, doi:10.1029/2006JD007463, 2007.

Solomon, S.: Stratospheric ozone depletion: A review of concepts and history, Rev. Geophys., 37, 275-316, 1999.

SPARC, Stratospheric Processes and Their Role in Climate: The Role of Halogen Chemistry in Polar Stratospheric Ozone Depletion: Report from the June 2008 Cambridge, UK Workshop for an Initiative under the Stratospheric Processes and Their Role in Climate (SPARC) Project of the World Climate Research Programme, available online at: http://www.atmosp.physics.utoronto.ca/SPARC/ HalogenChem_Final_20090213.pdf edited by: Kurylo, M. J. and Sinnhuber, B.-M., 48 pp., 2009.

SPARC CCMVal: SPARC Report on the Evaluation of ChemistryClimate Models, edited by: Eyring, V., Shepherd, T. G., Waugh, D. W., SPARC Report No. 5, WCRP-132, WMO/TD-No. 1526, 2010.

Tabazadeh, A., Santee, M. L., Danilin, M. Y., Pumphrey, H. C., Newman, P. A., Hamill, P. J., and Mergenthaler, J. L.: Quantifying denitrification and its effect on ozone recovery, Science, 288, 1407-1411, 2000.

Tsvetkova, N. D., Yushkov, V. A., Lukyanov, A. N., Dorokhov, V. M., and Nakane, H.: Record-breaking chemical destruction of ozone in the Arctic during the winter of 2004/2005, Izvestiya, Atmos. Ocean. Phys., 43, 592-598, 2007.

von Hobe, M., Ulanovsky, A., Volk, C. M., Grooß, J.-U., Tilmes, S., Konopka, P., Günther, G., Werner, A., Spelten, N., Shur, G., Yushkov, V., Ravegnani, F., Schiller, C., Müller, R., and Stroh, F.: Severe ozone depletion in the cold Arctic winter 2004-05, Geophys. Res. Lett., 33, doi:10.1029/2006GL026945, 2006.

von König, M., Bremer, H., Kleinböhl, A., Küllmann, H., Künzi, K. F., Goede, A. P. H., Browell, E. V., Grant, W. B., Buris, J. F., McGee, T. J., and Twigg, G.: Using gas-phase nitric acid as an indicator of PSC composition, J. Geophys. Res., 107, D20, 8265, 10.1029/2001JD00131, 2002.

Waibel, A. E., Peter, Th., Carslaw, K. S., Oelhaf, H., Wetzel, G., Crutzen, P. J., Pöschl, U., Tsias, A., Reimer, E., and Fischer, H.: Arctic ozone loss due to denitrification, Science, 283, 20642069, doi:10.1126/science.283.5410.2064, 1999.

Waters, J. W., Froidevaux, L., Harwood, R. S., Jarnot, R. F., Pickett, H. M., Read, W. G., Siegel, P. H., Cofield, R. E., Filipiak, M. J., Flower, D. A., Holden, J. R., Lau, G. K., Livesey, N. J., Manney, G. L., Pumphrey, H. C., Santee, M. L., Wu, D. L., Cuddy, 
D. T., Lay, R. R., Loo, M. S., Perun, V. S., Schwartz, M. J., Stek, P. C., Thurstans, R. P., Boyles, M. A., Chandra, K. M., Chavez, M. C., Chen, G. S., Chudasama, M. V., Dodge, R., Fuller, R. A., Girard, M. A., Jiang, J. J., Jiang, Y., Knosp, B. W., LaBelle, R. C., Lam, J. C., Lee, K. A., Miller, D., Oswlad, J. E., Patel, N. C., Pukala, D. M., Quintero, O., Scaff, D. M., Van Synder, W., Tope, M. C., Wagner, P. A., and Walch, M. J.: The Earth Observing System Microwave Limb Sounder (EOS MLS) on the Aura satellite, IEEE T. Geosci. Remote, 44, 1075-1092, 2006.
WMO (World Meteorological Organization): Scientific assessment of ozone depletion: 2010, Global Ozone Res. Monit. Proj. No., 52, Geneva, Switzerland, 2011. 